$$
\begin{aligned}
& \text { 도시와 농어촌지역 중 - 고등학생의 구강건강인식 및 구강보건 } \\
& \text { 의식행태 비교연구 } \\
& \text { 김민자 } 1 \text {, 양희정 } 2 \text {, 이승연 }{ }^{3} \\
& { }^{1} \text { 여주대학 치위생과, }{ }^{2} \text { 여주대학 보건행정과, }{ }^{3} \text { 원광대학교 보건행정학과 }
\end{aligned}
$$

\title{
A Comparative Study on Dental Health Perception and Dental Health Behaviors among Middle and High School Students in the Urban and Rural
}

\author{
Min-Ja Kim ${ }^{1}$, Hee-Jeong Yang ${ }^{2}$, Seung-Youn Lee ${ }^{3}$ \\ ${ }^{1}$ Department of Dental Hygienie, Yeoju College, \\ ${ }^{2}$ Department of Public Health Administration, Yegiu College, \\ ${ }^{3}$ Department of Public Health Administration, Wonkwang University
}

\begin{abstract}
$<$ Abstract $>$
A comparative study of the dental health perception and dental health behaviors among 12,325 middle and high school students in urban and rural areas was conducted by using "2010 National Dental Health Investigation." The results of this study are as follows.

For the dental health perception and the utilization of dental service, all middle and high school students had a low perception of the their dental health status toward the farming and fishing regions from the urban. For the time of tooth-brushing among the dental health behaviors, most middle and high school students brushed their teeth after lunch. In connection with the frequency of cariogenic snack intake, high school students had a greater percentage toward the farming and fishing regions from the urban. For the dental health status, middle school students in big cities had a high average of carious permanent teeth, but high school students had a high average of carious permanent teeth toward the farming and fishing regions from the urban. In other words, there was no significant difference in missing permanent teeth, filling permanent teeth and decay permanent teeth between middle school students by region, but high school students had a greater percentage of the dental health perception and dental health behaviors toward the farming and fishing regions from the urban, showing a little difference. Consequently, there was a relationship between middle and high school students' perception of dental health and their behaviors of dental health.
\end{abstract}

Key Words : Dental Health Behavior, Dental Health Perception, Middle and High School Students, Urban and Rural Regions 


\section{I. 서론}

과거에 비해 현대사회는 산업화·도시화·분업 화하는 경향들이 강하게 나타나고, 그 변화들 중 물질의 풍요, 편리한 생활, 의학의 발달은 인간수 명의 연장과 함께 건강을 지키기 위해 운동, 규칙 적인 습관, 금연, 금주 등을 지켜야 함을 강조하고 있지만 이들 또한 음식의 섭취가 잘 되어 영양을 골고루 섭취하고 있는 전제하에 가능한 것이므로 이는 곧 음식을 섭취하는 첫 관문인 구강이 건강 을 지키는 첫 관문이라는 것이다[1].

연구의 대상자인 청소년기는 신체적, 심리적, 그 리고 사회적으로 많은 변화를 겪는 시기이며, 자율 성이 증가하여 간식 섭취나 구강위생 관리에 있어 부모의 간섭이 줄어들고 자신의 책임이 증가하는 시기이다. 특히, 우리나라 청소년의 경우 학업과 각종 간식의 섭취 등의 문제로 건강관리를 소홀히 하는 경향이 있으며 구강위생 관리도 불량해져 구 강질환이 증가하고 있다. 실제로 2010년 국민구강 건강실태조사결과를 보면, 우식경험 영구치 지수 (DMFT index)가 12세에는 2.17인 반면 18-24세에 는 5.07로 두 배 이상 증가하는 것을 알 수 있다. 또한 청소년기는 구강위생관리의 소홀과 더불어 호르몬의 변화로 유년기에 비해 치주질환도 증가 하게 된다[2].

보건복지부(2010)의 국민구강건강실태 조사에서 나타난 우리나라 고등학교 1 학년 학생의 구강보건 실태를 살펴보면, 치아우식을 경험한 학생의 비율 은 $80.7 \%$ 이었고 우식경험영구치지수는 3.57 개로 나 타났다[3]. 충전영구치율은 남학생이 $72.8 \%$, 여학생 은 $78.0 \%$ 로 조사되었으며 치주상태에서 치은출혈 자율은 남학생이 $16.8 \%$, 여학생은 $15.5 \%$ 였고 치석 부착율은 여학생이 $45.1 \%$, 남학생은 $42.2 \%$ 로 나타 났다. 이들의 치과의료기관 이용률은 $45.2 \%$ 로 조사 되었으며, 구강건강행위 실천도는 잇솔질은 2.6-2.9 회였고 구강보조용품 가운데 치실 사용률은 $14.6 \%$
로 나타났다. 2005년 청소년의 흡연 실태에서도 청 소년건강행태 조사결과 흡연 경험률은 $28.15 \%$, 현 재흡연율은 $11.2 \%$ 이었다[4].

그럼에도 불구하고 치과 방문율은 낮은 편이다. 최근 연구에서는 $41 \%$ 만이 치과를 방문하였고[5], 특히 미취학 아동이나 청소년들의 치과 방문율이 낮았으며, 초·중·고등학교 재학생을 대상으로 한 2010년 국민구강건강실태조사에 따르면 지난 1년 동안 치과진료가 필요하다고 생각하였으나 진료를 받지 못한 비율은 $33.1 \%$ 이었다[6]. 또한 우리나라 국민의 약 $37 \%$ 가 최근 1 년 동안, 치과진료가 필요 하다고 생각하였으나 진료를 받지 못한 적이 있었 고, 이러한 필요 치과진료 미수진자는 사회경제적 위치가 낮은 집단에서 많았으며, 특히 병원이 멀리 떨어진 농어촌지역 학생들이 도시지역 학생들에 비해 매우 낮은 것으로 나타나 이에 대한 구체적 인 개선방안의 필요성이 제기된 바 있다[7]. 건강 하고 바람직한 구강행태가 일어나기 위해서는 긍 정적인 태도나 신념이 선행되어야 하고 먼저 올바 른 구강지식을 가지고 있어야 한다[8].

많은 선행연구에서 구강건강인식과 보건의식행 태에 관련된 요인의 경우 학생요인에 성별, 이전의 구강건강행위, 교육요인, 가정환경, 지역의 건강의 료시설 환경에 따라 영향을 받는 것으로 보고되고 있다[9]. 그 동안 구강건강인식과 구강보건의식행 태에 대한 연구는 다양한 집단을 대상으로 자기평 가에 관한 연구가 국-내외적으로 활성화되어 왔 다[10]. 또한 구강질환의 존재나 삶의 질과의 관계, 보건교육과의 관계에서의 연구도 누적되어 있다 [11]. 그렇지만 구강건강인식과 구강보건의식행태 와의 관계에 대한 의료시설이 잘 갖추어진 도시와 열악한 농어촌지역 청소년들 간 차이를 관찰한 연 구는 매우 부족하다. 특히, 중·고등학생을 대상으 로 한 구강건강에 관한 행동영역은 실생활에서 실 천할 수 있는 수준으로 잇솔질 시기, 횟수, 방법, 간식종류, 치과치료 목적 등의 실제 행위들에 대한 
연구들은 제한적으로 이루어져 왔다[12]. 그리고 중·고등학생의 구강건강증진행위와 관련된 인지지각 요인들이 상호간에 어떻게 영향을 미치는지 에 대한 총체적인 연구는 미비한 실정이다.

올바른 구강건강생활양식을 실천할 수 있도록 개인은 주도적인 책임을 가지고 구강건강 잠재능 력을 극대화할 수 있으며, 이것은 사회·심리적 요 인들에 의해 시작되고 조절될 수 있다. 학생들의 구강건강증진행위 또한 학생 개인뿐만 아니라 가 족과 지역사회의료 체계 등의 환경요인과 상호작 용하며, 결정된다고 볼 수 있다. 또한 학생이 사회 화 과정을 통해 습득하는 행위나 능력에는 부모나 가정환경에서 얻는 경험의 질 역시 매우 중요하다.

따라서 중·고등학생의 구강건강증진행위를 변 화시키고 바르게 인식시키기 위해서는 우선적으로 이와 관련된 인지-지각요인들이 도시와 농어촌간 어느 수준이며, 그 차이가 확인되어야 하며, 이 영 향요인들을 수행하거나 조절할 수 있는 구강건강 행태가 선행적으로 파악하여 교육적·이론적 시사 점을 모색하는데 본 연구의 목적을 갖는다.

\section{ㅍ. 연구방법}

1. 연구 대상

본 연구 대상은 2010년의 국민구강건강실태조사 자료를 이용하였으며, 16 개 도시내에서 시군구의 규모에 따라 지역규모(대도시, 중소도시와 군지역) 로 구분하고 그 중 남녀 중학생 1 학년 · 고등학생 1 학년 총 12,352 명을 대상으로 연구를 시행 하였다.

이중 중학생이 6,253명, 고등학생이 6,099명으로 지역별 측정이 가능한 항목을 선정하여 최종 분석 대상으로 하였다.
2. 연구 방법

1) 설문조사

설문조사 내용은 조사대상자가 구강건강과 관련 된 전신건강, 구강진료기관 이용실태, 구강보건의 식행태 및 구강건강과 관련된 보건의식행태와 조 사대상자의 일반적 특성을 파악하기 위한 문항 등 으로 구성되었다.

2) 자료분석

본 연구에서 수집된 자료는 SPSS ver18.0 통계 프로그램을 이용하여 대상자의 일반적인 특성은 빈도분석을 실시하였고, 대상자의 구강보건 의식 및 형태는 거주지별로 차이를 알아보기 위해 카이 제곱 검정을 시행하였다. 거주지별 구강건강상태를 알아보기 위해 평균과 표준편차를 산출하였으며 거주지별간의 유의한 차를 검증하기 위하여 분산 분석(ANOVA)을 통하여 분석하였으며 Duncan's analysis로 사후검정을 실시하였다. 유의수준은 0.05 이었다.

\section{III. 연구결과}

1. 연구대상자의 일반적 특성

조사대상자의 분포는 남학생 중 대도시 학생이 3,084 명, 중소도시 학생이 2,752명, 농어촌 학생이 930명이며, 여학생의 경우는 대도시 학생이 2,506 명, 중소도시 학생이 2,315명, 농어촌 학생이 765 명 이었다. 학급별로는 중학생이 6,253명, 고등학생이 6,099명으로 나타났다<표 1>. 
<표 1> 연구대상자의 일반적 특성

\begin{tabular}{|c|c|c|c|c|c|c|c|c|c|c|c|}
\hline & \multirow{2}{*}{ 구분 } & \multicolumn{3}{|c|}{ 대도시 } & \multicolumn{3}{|c|}{ 중소도시 } & \multicolumn{3}{|c|}{ 농촌 } & \multirow{2}{*}{ 전체 } \\
\hline & & 남 & 여 & 전체 & 남 & 여 & 전체 & 남 & 여 & 전체 & \\
\hline \multirow[t]{3}{*}{ 학년 } & 중학생 1학년 & 1,503 & 1,263 & 2,766 & 1,394 & 1,301 & 2,695 & 412 & 380 & 792 & 6,253 \\
\hline & 고등학생 1학년 & 1,581 & 1,243 & 2,824 & 1,358 & 1,014 & 2,372 & 518 & 385 & 903 & 6,099 \\
\hline & 계 & 3,084 & 2,506 & 5,590 & 2,752 & 2,315 & 5,067 & 930 & 765 & 1,695 & 12,352 \\
\hline
\end{tabular}

2. 구강건강인식 및 구강진료기관 이용실태

중학생 및 고등학생의 지역별 구강건강인식 및 구강진료기관 이용실태를 분석한 결과 주관적 구 강건강 상태를 보통으로 인식하고 있는 중학생은 농어촌 $53.2 \%$, 대도시 $51.8 \%$ 에 비해 중소도시가 $54.0 \%$ 로 약간 높았고, 건강하지 못함에서는 중소도 시 $19.4 \%$, 대도시 $16.6 \%$ 에 비해 농어촌이 $20.8 \%$ 로 약간 높았으며, 고등학생의 경우 중소도시 $46.5 \%$, 대도시 $45.7 \%$ 에 비해 농어촌이 $49.6 \%$ 로 약간 높았 다 $(\mathrm{p}<0.05)$.

지난 1년간 치과치료여부에 대한 조사에서는 중 학생의 경우 대도시 $55.3 \%$ 가 치과치료를 받았으며 그 뒤를 중소도시 $52.8 \%$, 농어촌 $50.4 \%$ 로 나타난 반면 고등학생의 경우 이와 반대로 농어촌 $58.6 \%$, 중소도시 $55.5 \%$, 대도시 $53.9 \%$ 로 지난 1년간 치과 치료를 받은 적이 없다고 나타났다.
지난 1 년간 미충족 치료 필요여부에 대해서는 대도시 $67.7 \%$, 농어촌 $67.7 \%$, 중소도시 $67.4 \%$ 가 '아 니오'로 나타났으며, 고등학생의 경우 또한 대도시 $55.2 \%$, 중소도시 $55.2 \%$, 농어촌 $55.0 \%$ 로 '아니오'로 나타난 비율이 지역별로 별다른 차이가 없었다.

미충족 치료 필요 원인에 따른 조사에서는 '치 과진료를 받는게 무서워' 치료를 받지 않는 중학생 의 경우 농어촌 $22.7 \%$ 로 중소도시 $15.4 \%$, 대도시 의 $18.0 \%$ 에 비해 높았으나 '내가 갈수 있는 시간 에 문을 열지 않아서의 경우' 대도시 $17.0 \%$ 로 중 소도시 $13.7 \%$, 농어촌 $12.3 \%$ 에 비해 높았다 $(\mathrm{p}<0.05)$.

고등학생의 경우 '치과가기 싫어서' 진료를 받지 않는 경우는 농어촌 $27.3 \%$ 로 대도시 $23.5 \%$ 와 중소 도시 $22.3 \%$ 에 비해 많은 차이를 나타났다 $(\mathrm{p}<0.05)$ <표 2>. 
<표 2> 구강건강인식 및 구강진료기관 이용실태

\begin{tabular}{|c|c|c|c|c|c|c|c|c|c|c|c|}
\hline \multirow{2}{*}{ 항 목 } & \multirow{2}{*}{ 구 분 } & \multicolumn{4}{|c|}{ 중학생 1학년 } & \multicolumn{6}{|c|}{ 고등학생 1학년 } \\
\hline & & 대도시 & 중소도시 & 농어촌 & 계 & $p$ & 대도시 & 중소도시 & 농어촌 & 계 & $p$ \\
\hline \multirow{6}{*}{$\begin{array}{l}\text { 주관적 구강 } \\
\text { 건강 상태 }\end{array}$} & 매우 건강함 & $\begin{array}{r}137 \\
(5.0)\end{array}$ & $\begin{array}{r}113 \\
(4.2)\end{array}$ & $\begin{array}{r}23 \\
(3.7)\end{array}$ & $\begin{array}{r}279 \\
(4.5)\end{array}$ & .001 & $\begin{array}{r}79 \\
(2.8)\end{array}$ & $\begin{array}{r}82 \\
(3.5)\end{array}$ & $\begin{array}{r}23 \\
(2.5)\end{array}$ & $\begin{array}{r}184 \\
(3.0)\end{array}$ & .001 \\
\hline & 건강함 & $\begin{array}{r}674 \\
(24.4)\end{array}$ & $\begin{array}{r}547 \\
(20.3)\end{array}$ & $\begin{array}{r}163 \\
(20.6)\end{array}$ & $\begin{array}{l}1,384 \\
(22.2)\end{array}$ & & $\begin{array}{r}625 \\
(22.2)\end{array}$ & $\begin{array}{r}478 \\
(20.2)\end{array}$ & $\begin{array}{r}147 \\
(16.3)\end{array}$ & $\begin{array}{l}1,250 \\
(20.5)\end{array}$ & \\
\hline & 보통 & $\begin{array}{l}1,432 \\
(51.8)\end{array}$ & $\begin{array}{l}1,454 \\
(54.0)\end{array}$ & $\begin{array}{r}421 \\
(53.2)\end{array}$ & $\begin{array}{l}3,307 \\
(53.0)\end{array}$ & & $\begin{array}{l}1,288 \\
(45.7)\end{array}$ & $\begin{array}{l}1,102 \\
(46.5)\end{array}$ & $\begin{array}{r}447 \\
(49.6)\end{array}$ & $\begin{array}{l}2,837 \\
(46.6)\end{array}$ & \\
\hline & 건강하지 못함 & $\begin{array}{r}458 \\
(16.6)\end{array}$ & $\begin{array}{r}523 \\
(19.4)\end{array}$ & $\begin{array}{r}165 \\
(20.8)\end{array}$ & $\begin{array}{l}1,146 \\
(18.4)\end{array}$ & & $\begin{array}{r}748 \\
(26.5)\end{array}$ & $\begin{array}{r}628 \\
(26.5)\end{array}$ & $\begin{array}{r}241 \\
(26.7)\end{array}$ & $\begin{array}{l}1,617 \\
(26.5)\end{array}$ & \\
\hline & 매우 건강하지 못함 & $\begin{array}{r}61 \\
(2.2)\end{array}$ & $\begin{array}{r}54 \\
(2.0)\end{array}$ & $\begin{array}{r}14 \\
(1.8)\end{array}$ & $\begin{array}{r}129 \\
(2.1)\end{array}$ & & $\begin{array}{r}78 \\
(2.8)\end{array}$ & $\begin{array}{r}82 \\
(3.5)\end{array}$ & $\begin{array}{r}44 \\
(4.9)\end{array}$ & $\begin{array}{r}204 \\
(3.3)\end{array}$ & \\
\hline & 전체 & $\begin{array}{r}2,762 \\
(100.0)\end{array}$ & $\begin{array}{r}2,691 \\
(100.0)\end{array}$ & $\begin{array}{r}792 \\
(100.0)\end{array}$ & $\begin{array}{r}6,245 \\
(100.0)\end{array}$ & & $\begin{array}{r}2,818 \\
(100.0)\end{array}$ & $\begin{array}{r}2,372 \\
(100.0)\end{array}$ & $\begin{array}{r}902 \\
(100.0)\end{array}$ & $\begin{array}{r}6,092 \\
(100.0)\end{array}$ & \\
\hline \multirow{3}{*}{$\begin{array}{l}\text { 지난 1년간 } \\
\text { 치과치료 } \\
\text { 여부 }\end{array}$} & 예 & $\begin{array}{l}1,529 \\
(55.3)\end{array}$ & $\begin{array}{l}1,423 \\
(52.8)\end{array}$ & $\begin{array}{r}399 \\
(50.4)\end{array}$ & $\begin{array}{l}3,351 \\
(53.6)\end{array}$ & .027 & $\begin{array}{l}1,301 \\
(46.1)\end{array}$ & $\begin{array}{l}1,055 \\
(44.5)\end{array}$ & $\begin{array}{r}373 \\
(41.4)\end{array}$ & $\begin{array}{l}2,729 \\
(44.8)\end{array}$ & .043 \\
\hline & 아니오 & $\begin{array}{l}1,235 \\
(44.7)\end{array}$ & $\begin{array}{l}1,271 \\
(47.2)\end{array}$ & $\begin{array}{r}393 \\
(49.6)\end{array}$ & $\begin{array}{l}2,899 \\
(46.4)\end{array}$ & & $\begin{array}{l}1,523 \\
(53.9)\end{array}$ & $\begin{array}{l}1,317 \\
(55.5)\end{array}$ & $\begin{array}{r}529 \\
(58.6)\end{array}$ & $\begin{array}{l}3,369 \\
(55.2)\end{array}$ & \\
\hline & 전체 & $\begin{array}{r}2,764 \\
(100.0)\end{array}$ & $\begin{array}{r}2,694 \\
(100.0)\end{array}$ & $\begin{array}{r}792 \\
(100.0)\end{array}$ & $\begin{array}{r}6,250 \\
(100.0)\end{array}$ & & $\begin{array}{r}2,824 \\
(100.0)\end{array}$ & $\begin{array}{r}2,372 \\
(100.0)\end{array}$ & $\begin{array}{r}902 \\
(100.0)\end{array}$ & $\begin{array}{r}6,098 \\
(100.0)\end{array}$ & \\
\hline \multirow{3}{*}{$\begin{array}{l}\text { 지난 1년간 } \\
\text { 미충족 치료 } \\
\text { 필요여부 }\end{array}$} & 예 & $\begin{array}{r}719 \\
(32.3)\end{array}$ & $\begin{array}{r}711 \\
(32.6)\end{array}$ & $\begin{array}{r}210 \\
(32.3)\end{array}$ & $\begin{array}{l}1,640 \\
(32.4)\end{array}$ & .975 & $\begin{array}{l}1,050 \\
(44.8)\end{array}$ & $\begin{array}{r}899 \\
(44.8)\end{array}$ & $\begin{array}{r}331 \\
(45.0)\end{array}$ & $\begin{array}{l}2,280 \\
(44.8)\end{array}$ & .996 \\
\hline & 아니오 & $\begin{array}{l}1,506 \\
(67.7)\end{array}$ & $\begin{array}{r}1,469 \\
(67.4)\end{array}$ & $\begin{array}{r}440 \\
(67.7)\end{array}$ & $\begin{array}{l}3,415 \\
(67.6)\end{array}$ & & $\begin{array}{l}1,295 \\
(55.2)\end{array}$ & $\begin{array}{l}1,106 \\
(55.2)\end{array}$ & $\begin{array}{r}405 \\
(55.0)\end{array}$ & $\begin{array}{l}2,806 \\
(55.2)\end{array}$ & \\
\hline & 전체 & $\begin{array}{r}2,225 \\
(100.0)\end{array}$ & $\begin{array}{r}2,180 \\
(100.0)\end{array}$ & $\begin{array}{r}650 \\
(100.0)\end{array}$ & $\begin{array}{r}5,055 \\
(100.0)\end{array}$ & & $\begin{array}{r}2,345 \\
(100.0)\end{array}$ & $\begin{array}{r}2,005 \\
(100.0)\end{array}$ & $\begin{array}{r}736 \\
(100.0)\end{array}$ & $\begin{array}{r}5,086 \\
(100.0)\end{array}$ & \\
\hline \multirow{9}{*}{$\begin{array}{l}\text { 미충족 치료 } \\
\text { 필요 원인 }\end{array}$} & 치과진료 받는게 무서워서 & $\begin{array}{r}131 \\
(18.0)\end{array}$ & $\begin{array}{r}109 \\
(15.4)\end{array}$ & $\begin{array}{r}48 \\
(22.7)\end{array}$ & $\begin{array}{r}288 \\
(17.5)\end{array}$ & .002 & $\begin{array}{r}177 \\
(16.6)\end{array}$ & $\begin{array}{r}144 \\
(15.8)\end{array}$ & $\begin{array}{r}54 \\
(16.2)\end{array}$ & $\begin{array}{r}375 \\
(16.2)\end{array}$ & .018 \\
\hline & 치과에 가기 싫어서 & $\begin{array}{r}179 \\
(24.6)\end{array}$ & $\begin{array}{r}170 \\
(24.0)\end{array}$ & $\begin{array}{r}44 \\
(20.9)\end{array}$ & $\begin{array}{r}393 \\
(23.9)\end{array}$ & & $\begin{array}{r}250 \\
(23.5)\end{array}$ & $\begin{array}{r}203 \\
(22.3)\end{array}$ & $\begin{array}{r}91 \\
(27.3)\end{array}$ & $\begin{array}{r}544 \\
(23.6)\end{array}$ & \\
\hline & 경제적 부담 되어서 & $\begin{array}{r}52 \\
(7.1)\end{array}$ & $\begin{array}{r}39 \\
(5.5)\end{array}$ & $\begin{array}{r}7 \\
\text { (3.3) }\end{array}$ & $\begin{array}{r}98 \\
(6.0)\end{array}$ & & $\begin{array}{r}173 \\
(16.2)\end{array}$ & $\begin{array}{r}132 \\
(14.5)\end{array}$ & $\begin{array}{r}32 \\
(9.6)\end{array}$ & $\begin{array}{r}337 \\
(14.6)\end{array}$ & \\
\hline & 교통 불편해서 & $\begin{array}{r}15 \\
(2.1)\end{array}$ & $\begin{array}{r}21 \\
(3.0)\end{array}$ & $\begin{array}{r}5 \\
(2.4)\end{array}$ & $\begin{array}{r}41 \\
(2.5)\end{array}$ & & $\begin{array}{r}21 \\
(2.0)\end{array}$ & $\begin{array}{r}15 \\
(1.7)\end{array}$ & $\begin{array}{r}15 \\
(4.5)\end{array}$ & $\begin{array}{r}51 \\
(2.2)\end{array}$ & \\
\hline & $\begin{array}{l}\text { 치과에 같이 갈 사람이 } \\
\text { 없어서 }\end{array}$ & $\begin{array}{r}27 \\
(3.7)\end{array}$ & $\begin{array}{r}32 \\
(4.5)\end{array}$ & $\begin{array}{r}19 \\
(9.0)\end{array}$ & $\begin{array}{r}78 \\
(4.7)\end{array}$ & & $\begin{array}{r}19 \\
(1.8)\end{array}$ & $\begin{array}{r}19 \\
(2.1)\end{array}$ & $\begin{array}{r}11 \\
(3.3)\end{array}$ & $\begin{array}{r}49 \\
(2.1)\end{array}$ & \\
\hline & $\begin{array}{l}\text { 내가 갈 수 있는 시간에 } \\
\text { 치과가 문을 열지 않아서 }\end{array}$ & $\begin{array}{r}124 \\
(17.0)\end{array}$ & $\begin{array}{r}97 \\
(13.7)\end{array}$ & $\begin{array}{r}26 \\
(12.3)\end{array}$ & $\begin{array}{r}247 \\
(15.0)\end{array}$ & & $\begin{array}{r}168 \\
(15.8)\end{array}$ & $\begin{array}{r}172 \\
(18.9)\end{array}$ & $\begin{array}{r}57 \\
(17.1)\end{array}$ & $\begin{array}{r}397 \\
(17.2)\end{array}$ & \\
\hline & 오래 기다리기 싫어서 & $\begin{array}{r}39 \\
(5.4)\end{array}$ & $\begin{array}{r}30 \\
(4.2)\end{array}$ & $\begin{array}{r}11 \\
(5.2)\end{array}$ & $\begin{array}{r}80 \\
(4.9)\end{array}$ & & $\begin{array}{r}31 \\
(2.9)\end{array}$ & $\begin{array}{r}27 \\
(3.0)\end{array}$ & $\begin{array}{r}12 \\
(3.6)\end{array}$ & $\begin{array}{r}70 \\
(3.0)\end{array}$ & \\
\hline & 기타 & $\begin{array}{r}161 \\
(22.1)\end{array}$ & $\begin{array}{r}210 \\
(29.7)\end{array}$ & $\begin{array}{r}51 \\
(24.2)\end{array}$ & $\begin{array}{r}422 \\
(25.6)\end{array}$ & & $\begin{array}{r}227 \\
(21.3)\end{array}$ & $\begin{array}{r}197 \\
(21.7)\end{array}$ & $\begin{array}{r}61 \\
(18.3)\end{array}$ & $\begin{array}{r}485 \\
(21.0)\end{array}$ & \\
\hline & 전체 & $\begin{array}{r}728 \\
(100.0)\end{array}$ & $\begin{array}{r}708 \\
(100.0)\end{array}$ & $\begin{array}{r}211 \\
(100.0)\end{array}$ & $\begin{array}{r}1,647 \\
(100.0)\end{array}$ & & $\begin{array}{r}1,066 \\
(100.0)\end{array}$ & $\begin{array}{r}909 \\
(100.0)\end{array}$ & $\begin{array}{r}333 \\
(100.0)\end{array}$ & $\begin{array}{r}2,308 \\
(100.0)\end{array}$ & \\
\hline
\end{tabular}

카이제곱 검정, $\mathrm{p}<0.05$

결측자료 제외하고 카이제곱한 결과임 


\section{3. 구강보건의식행태 I}

중학생의 경우 1 일 잇솔질 시기는 '아침식사 후' 가장 많이 하고 있으며 대도시 $29.1 \%$ 으로서 중소 도시 $28.8 \%$, 농어촌 $27.8 \%$ 에 비해 높았고 '잠자기 직전'의 경우도 대도시 $26.1 \%$ 가 중소도시 $25.6 \%$, 농어촌 $23.1 \%$ 에 비해 높았으나 점식식사 후의 경 우 대도시의 $8.2 \%$ 가 농어촌 $11.5 \%$, 중소도시의 $7.9 \%$ 에 비해 많이 낮았다 $(\mathrm{p}<0.001)$.

또한 구강위생 보조용품 사용여부에 대해서는 치실, 양치용액, 전동칫솔, 기타용품은 대도시 지역
과 농어촌지역간에 유의한 차이가 없었다.

고등학생의 경우 '아침식사 후' 가장 많이 잇솔 질을 하고 있으며 농어촌 $27.0 \%$ 으로 대도시 $25.7 \%$ 와 중소도시 $25.3 \%$ 에 비해 높게 나타났으며, '잠자 기 직전'의 경우는 대도시 $25.3 \%$ 으로 중소도시 $22.7 \%$, 농어촌 $21.9 \%$ 에 비해 높게 나타났다 $(\mathrm{p}<0.001)$.

구강위생 보조용품 사용여부에 대해서는 중학생 과 마찬가지로 치실, 양치용액, 전동칫솔, 기타용품 은 대도시 지역과 농어촌지역간에 유의한 차이가 없었다<표 3>.

<표 3> 구강보건의식행태 |

\begin{tabular}{|c|c|c|c|c|c|c|c|c|c|c|c|}
\hline \multirow{2}{*}{ 항 목 } & \multirow{2}{*}{ 구 분 } & \multicolumn{4}{|c|}{ 중학생 1학년 } & \multicolumn{6}{|c|}{ 고등학생 1학년 } \\
\hline & & 대도시 & 중소도시 & 농어촌 & 계 & $\mathrm{p}$ & 대도시 & 중소도시 & 농어촌 & 계 & $p$ \\
\hline \multirow[t]{6}{*}{ 1일 잇솔질 시기 } & 아침식사 전 & $\begin{array}{r}820 \\
(11.3)\end{array}$ & $\begin{array}{r}828 \\
(11.9)\end{array}$ & $\begin{array}{r}260 \\
(12.3)\end{array}$ & $\begin{array}{l}1,908 \\
(11.7)\end{array}$ & .000 & $\begin{array}{r}953 \\
(12.3)\end{array}$ & $\begin{array}{r}724 \\
(10.2)\end{array}$ & $\begin{array}{r}269 \\
(10.6)\end{array}$ & $\begin{array}{l}1,946 \\
(11.2)\end{array}$ & .000 \\
\hline & 아침식사 후 & $\begin{array}{l}2,104 \\
(29.1)\end{array}$ & $\begin{array}{l}2,010 \\
(28.8)\end{array}$ & $\begin{array}{r}588 \\
(27.8)\end{array}$ & $\begin{array}{l}4,702 \\
(28.8)\end{array}$ & & $\begin{array}{l}1,985 \\
(25.7)\end{array}$ & $\begin{array}{l}1,793 \\
(25.3)\end{array}$ & $\begin{array}{r}682 \\
(27.0)\end{array}$ & $\begin{array}{l}4,460 \\
(25.7)\end{array}$ & \\
\hline & 점심식사 후 & $\begin{array}{r}593 \\
(8.2)\end{array}$ & $\begin{array}{r}552 \\
(7.9)\end{array}$ & $\begin{array}{r}243 \\
(11.5)\end{array}$ & $\begin{array}{r}1,388 \\
(8.5)\end{array}$ & & $\begin{array}{l}1,178 \\
(15.2)\end{array}$ & $\begin{array}{l}1,359 \\
(19.2)\end{array}$ & $\begin{array}{r}463 \\
(18.3)\end{array}$ & $\begin{array}{l}3,000 \\
(17.3)\end{array}$ & \\
\hline & 저녁식사 후 & $\begin{array}{l}1,825 \\
(25.3)\end{array}$ & $\begin{array}{l}1,799 \\
(25.8)\end{array}$ & $\begin{array}{r}536 \\
(25.3)\end{array}$ & $\begin{array}{l}4,160 \\
(25.5)\end{array}$ & & $\begin{array}{l}1,656 \\
(21.4)\end{array}$ & $\begin{array}{l}1,597 \\
(22.6)\end{array}$ & $\begin{array}{r}563 \\
(22.3)\end{array}$ & $\begin{array}{l}3,816 \\
(22.0)\end{array}$ & \\
\hline & 잠자기 직전 & $\begin{array}{l}1,883 \\
(26.1)\end{array}$ & $\begin{array}{r}1,786 \\
(25.6)\end{array}$ & $\begin{array}{r}490 \\
(23.1)\end{array}$ & $\begin{array}{l}4,159 \\
(25.5)\end{array}$ & & $\begin{array}{l}1,957 \\
(25.3)\end{array}$ & $\begin{array}{l}1,609 \\
(22.7)\end{array}$ & $\begin{array}{r}553 \\
(21.9)\end{array}$ & $\begin{array}{l}4,119 \\
(23.8)\end{array}$ & \\
\hline & 전체 & $\begin{array}{r}7,225 \\
(100.0) \\
\end{array}$ & $\begin{array}{r}6,975 \\
(100.0) \\
\end{array}$ & $\begin{array}{r}2,117 \\
(100.0)\end{array}$ & $\begin{array}{r}16,317 \\
(100.0)\end{array}$ & & $\begin{array}{r}7,729 \\
(100.0)\end{array}$ & $\begin{array}{r}7,082 \\
(100.0) \\
\end{array}$ & $\begin{array}{r}2,530 \\
(100.0) \\
\end{array}$ & $\begin{array}{r}17,341 \\
(100.0)\end{array}$ & \\
\hline \multirow{5}{*}{$\begin{array}{l}\text { 구강위생 보조용품 } \\
\text { 사용여부 }\end{array}$} & 치실 & $\begin{array}{l}2,290 \\
(24.2)\end{array}$ & $\begin{array}{l}2,319 \\
(24.7)\end{array}$ & $\begin{array}{r}672 \\
(24.9)\end{array}$ & $\begin{array}{l}5,281 \\
(24.5)\end{array}$ & .965 & $\begin{array}{l}2,515 \\
(24.7)\end{array}$ & $\begin{array}{l}2,106 \\
(24.6)\end{array}$ & $\begin{array}{r}823 \\
(25.1)\end{array}$ & $\begin{array}{l}5,444 \\
(24.7)\end{array}$ & .998 \\
\hline & 양치용액 & $\begin{array}{l}2,107 \\
(22.3)\end{array}$ & $\begin{array}{l}2,086 \\
(22.3)\end{array}$ & $\begin{array}{r}584 \\
(21.7)\end{array}$ & $\begin{array}{l}4,777 \\
(22.2)\end{array}$ & & $\begin{array}{l}2,317 \\
(22.8)\end{array}$ & $\begin{array}{l}1,971 \\
(23.0)\end{array}$ & $\begin{array}{r}749 \\
(22.8)\end{array}$ & $\begin{array}{l}5,037 \\
(22.9)\end{array}$ & \\
\hline & 전동칫솔 & $\begin{array}{l}2,374 \\
(25.1)\end{array}$ & $\begin{array}{l}2,329 \\
(24.9)\end{array}$ & $\begin{array}{r}675 \\
(25.1)\end{array}$ & $\begin{array}{l}5,378 \\
(25.0)\end{array}$ & & $\begin{array}{l}2,572 \\
(25.3)\end{array}$ & $\begin{array}{l}2,156 \\
(25.2)\end{array}$ & $\begin{array}{r}817 \\
(24.9)\end{array}$ & $\begin{array}{l}5,545 \\
(25.2)\end{array}$ & \\
\hline & 기타용품 & $\begin{array}{l}2,692 \\
(28.4)\end{array}$ & $\begin{array}{l}2,638 \\
(28.1)\end{array}$ & $\begin{array}{r}763 \\
(28.3)\end{array}$ & $\begin{array}{l}6,093 \\
(28.3)\end{array}$ & & $\begin{array}{l}2,765 \\
(27.2)\end{array}$ & $\begin{array}{l}2,319 \\
(27.1)\end{array}$ & $\begin{array}{r}891 \\
(27.2)\end{array}$ & $\begin{array}{l}5,975 \\
(27.2)\end{array}$ & \\
\hline & 전체 & $\begin{array}{r}9,463 \\
(100.0)\end{array}$ & $\begin{array}{r}9,372 \\
(100.0)\end{array}$ & $\begin{array}{r}2,94 \\
(100.0)\end{array}$ & $\begin{array}{l}21,529 \\
(100.0)\end{array}$ & & $\begin{array}{l}10,169 \\
(100.0)\end{array}$ & $\begin{array}{r}8,552 \\
(100.0)\end{array}$ & $\begin{array}{r}3,280 \\
(100.0)\end{array}$ & $\begin{array}{l}22,001 \\
(100.0)\end{array}$ & \\
\hline
\end{tabular}

복수응답 결과에 가중치 부여하여 교차분석함 
4. 구강보건의식행태 ㅍ

중학생의 경우 1 일 우식성 간식섭취 횟수는 농 어촌 $46.3 \%$, 대도시 $44.0 \%$, 중소도시 $43.8 \%$ 로 $2-3$ 번 우식성 간식섭취를 가장 많이 하는 것으로 나 타났으며 1 번의 경우 이와는 다르게 대도시 $33.4 \%$, 중소도시 $32.5 \%$, 농어촌 $27.8 \%$ 로 반대의 경우로 조사 되었으나 중학생의 1 일 우식성 간식섭취 횟 수에 따른 지역별 구분은 유의한 차이는 없었다.

고등학생의 경우 1 일 우식성 간식섭취 횟수는 농어촌 $48.1 \%$, 중소도시 $47.4 \%$, 대도시 $46.4 \%$ 로 2-3번 우식성 간식섭취를 가장 많이 하는 것으로 나타났으며 1 번의 경우 이와는 다르게 중소도시 $29.0 \%$, 대도시 $28.6 \%$, 농어촌 $26.8 \%$ 로 반대의 경우 로 조사되었으나 고등학생의 1 일 우식성 간식섭취 횟수에 따른 지역별 구분은 유의한 차이를 보이고 있다( $\mathrm{p}<0.05)$.

1 일 우식성 음료섭취 횟수는 중학생의 경우 대 도시 $37.8 \%$, 중소도시 $37.1 \%$, 농어촌 $37.0 \%$ 으로 1 번 섭취를 가장 많이 하는 것으로 나타났으며 그 다음으로는 의외로 대도시 $37.8 \%$, 중소도시 $37.5 \%$, 농어촌 $37.1 \%$ 으로 먹지 않는다는 것으로 나타났다. 고등학생의 경우 1 일 우식성 음료섭취 횟수는 지 역별로 유의한 차이가 없었다.

흡연경험여부에 대해서는 중학생의 경우 대부분 이 흡연을 하지 않는다고 나타났으며 대도시 $91.8 \%$, 중소도시 $91.2 \%$, 농어촌 $89.3 \%$ 으로 나타났 으나 유의한 차이는 없었다. 중학생과는 다르게 고 등학생의 경우 흡연을 하지 않는다는 비율이 중소 도시 $78.4 \%$, 대도시 $77.9 \%$, 농어촌 $68.4 \%$ 으로 중소 도시의 흡연을 하지 않은 학생의 비율이 높게 나 타났으며 지역별로 유의한 차이를 보이고 있다 $(\mathrm{p}<0.05)$.

흡연상태를 묻는 질문에서는 중학생의 경우 현 재 흡연을 하지 않는다는 학생의 비율이 대도시 $94.3 \%$, 중소도시 $93.2 \%$, 농어촌 $93.1 \%$ 순서로 나타
났다. 과거에는 피웠으나 현재는 끓었다는 비율은 흡연을 하지 않는다는 지역들과 다르게 농어촌 $6.6 \%$, 중소도시 $6.3 \%$, 대도시 $4.9 \%$ 으로 농어촌의 비율이 높게 나타났다. 고등학생의 경우 중소도시 $82.4 \%$, 대도시 $81.5 \%$, 농어촌 $74.4 \%$ 으로 중소도시 의 학생이 현재 흡연을 하지 않는다는 것이 높게 나타났으며 중학생과는 다르게 현재 흡연을 하는 비율이 농어촌 $11.2 \%$, 중소도시 $6.5 \%$, 대도시 $6.2 \%$ 순서로 나타났으며 지역별로 유의한 차이를 보이 고 있다 $(\mathrm{p}<0.001)$.

지난 한달 동안 흡연을 하지 않은 중학생의 경 우 중소도시 $98.2 \%$, 대도시 $97.8 \%$, 농어촌 $97.7 \%$ 으 로 대부분이 지난 한 달 동안 흡연을 하지 않았으 며, 고등학생의 경우 대도시 $90.7 \%$, 중소도시 $90.2 \%$, 농어촌 $84.7 \%$ 으로 지역별로 유의한 차이를 보이고 있다 $(\mathrm{p}<0.001)<$ 표 $4>$.

5. 학년 · 거주지별 구강건강상태 비교

학년 - 거주지별 구강건강상태를 비교한 결과 중 학생 우식영구치수 평균은 0.60 개, 중소도시 0.56 개, 농어촌 0.39 개이었고, 고등학생의 경우 중학생 과 반대로 농어촌 0.91 개, 중소도시 0.68 개, 대도시 0.56개로 지역별 우식영구치수는 유의한 차이를 보 이고 있다 $(\mathrm{p}<0.001)$.

상실영구치수의 경우 중학생과 고등학생의 지역 별 차이는 통계적으로 유의한 차이를 보이지 않았 다. 충전영구치수의 경우와 우식경험영구치수의 경 우 중학생은 지역별로 유의한 차이를 보이지 않았 으며 고등학생의 경우 충전영구치수는 농어촌 2.65 개, 중소도시 2.29개, 대도시 2.21개로 나타났으며 우식경험영구치수의 경우 또한 농어촌 3.58 개, 중 소도시 2.99개, 대도시 2.78 개로 농어촌이 대도시에 비해 높은 평균을 나타냈으며 유의한 차이를 보이 고 있다<표 5>. 
<표 4> 구강보건의식행태 II

\begin{tabular}{|c|c|c|c|c|c|c|c|c|c|c|c|}
\hline \multirow{2}{*}{ 항 목 } & \multirow{2}{*}{ 구 분 } & \multicolumn{4}{|c|}{ 중학생 1학년 } & \multicolumn{6}{|c|}{ 고등학생 1학년 } \\
\hline & & 대도시 & 중소도시 & 농어촌 & 계 & $p$ & 대도시 & 중소도시 & 농어촌 & 계 & $p$ \\
\hline 1일 우식성 & 먹지않음 & $\begin{array}{r}284 \\
(10.3)\end{array}$ & $\begin{array}{r}259 \\
(9.6)\end{array}$ & $\begin{array}{r}90 \\
(11.4)\end{array}$ & $\begin{array}{r}633 \\
(10.1)\end{array}$ & ".080 & $\begin{array}{r}261 \\
(9.3)\end{array}$ & $\begin{array}{r}207 \\
(8.7)\end{array}$ & $\begin{array}{r}66 \\
(7.3)\end{array}$ & $\begin{array}{r}534 \\
(8.8)\end{array}$ & .002. \\
\hline \multirow[t]{5}{*}{ 간식섭취 횟수 } & 1번 & $\begin{array}{r}924 \\
(33.4)\end{array}$ & $\begin{array}{r}874 \\
(32.5)\end{array}$ & $\begin{array}{r}220 \\
(27.8)\end{array}$ & $\begin{array}{l}2018 \\
\text { (32.) }\end{array}$ & & $\begin{array}{r}807 \\
(28.6)\end{array}$ & $\begin{array}{r}687 \\
(29.0)\end{array}$ & $\begin{array}{r}242 \\
(26.8)\end{array}$ & $\begin{array}{l}1,736 \\
(28.5)\end{array}$ & \\
\hline & 2-3번 & $\begin{array}{l}1,215 \\
(44.0)\end{array}$ & $\begin{array}{l}1,180 \\
(43.8)\end{array}$ & $\begin{array}{r}367 \\
(46.3)\end{array}$ & $\begin{array}{l}2,762 \\
(44.2)\end{array}$ & & $\begin{array}{l}1,309 \\
(46.4)\end{array}$ & $\begin{array}{l}1,125 \\
(47.4)\end{array}$ & $\begin{array}{r}434 \\
(48.1)\end{array}$ & $\begin{array}{l}2,868 \\
(47.1)\end{array}$ & \\
\hline & 4번 이상 & $\begin{array}{r}223 \\
(8.1)\end{array}$ & $\begin{array}{r}251 \\
(9.3)\end{array}$ & $\begin{array}{r}81 \\
(10.2)\end{array}$ & $\begin{array}{r}555 \\
(8.9)\end{array}$ & & $\begin{array}{r}341 \\
(12.1)\end{array}$ & $\begin{array}{r}272 \\
(11.5)\end{array}$ & $\begin{array}{r}100 \\
(11.1)\end{array}$ & $\begin{array}{r}713 \\
(11.7)\end{array}$ & \\
\hline & 모르겠음 & $\begin{array}{r}118 \\
(4.3)\end{array}$ & $\begin{array}{r}128 \\
(4.8)\end{array}$ & $\begin{array}{r}34 \\
(10.2) \\
\end{array}$ & $\begin{array}{r}280 \\
(4.5)\end{array}$ & & $\begin{array}{r}102 \\
(3.6)\end{array}$ & $\begin{array}{r}81 \\
(3.4)\end{array}$ & $\begin{array}{r}60 \\
(6.7) \\
\end{array}$ & $\begin{array}{r}243 \\
(4.0)\end{array}$ & \\
\hline & 전체 & $\begin{array}{r}2,764 \\
(100.0)\end{array}$ & $\begin{array}{r}2,692 \\
(100.0) \\
\end{array}$ & $\begin{array}{r}792 \\
(100.0)\end{array}$ & $\begin{array}{r}6248 \\
(100.0)\end{array}$ & & $\begin{array}{r}2,820 \\
(100.0)\end{array}$ & $\begin{array}{r}2,372 \\
(100.0) \\
\end{array}$ & $\begin{array}{r}902 \\
(100.0)\end{array}$ & $\begin{array}{r}6,094 \\
(100.0)\end{array}$ & \\
\hline 1일 우식성 & 먹지않음 & $\begin{array}{l}1,042 \\
(37.8)\end{array}$ & $\begin{array}{l}1,010 \\
(37.5)\end{array}$ & $\begin{array}{r}267 \\
(33.8)\end{array}$ & $\begin{array}{l}2,319 \\
(37.1)\end{array}$ & .278 & $\begin{array}{r}935 \\
(33.1)\end{array}$ & $\begin{array}{r}779 \\
(32.8)\end{array}$ & $\begin{array}{r}310 \\
(34.4)\end{array}$ & $\begin{array}{l}2,024 \\
(33.2)\end{array}$ & .007 \\
\hline \multirow[t]{5}{*}{ 음료섭취 횟수 } & 1번 & $\begin{array}{r}1,045 \\
(37.8)\end{array}$ & $\begin{array}{r}998 \\
(37.1)\end{array}$ & $\begin{array}{r}292 \\
(37.0)\end{array}$ & $\begin{array}{l}2,335 \\
(37.4)\end{array}$ & & $\begin{array}{l}1,104 \\
(39.1)\end{array}$ & $\begin{array}{r}923 \\
(38.9)\end{array}$ & $\begin{array}{r}332 \\
(36.8)\end{array}$ & $\begin{array}{l}2,359 \\
(38.7)\end{array}$ & \\
\hline & 2 3번 & $\begin{array}{r}526 \\
(19.0)\end{array}$ & $\begin{array}{r}521 \\
(19.4)\end{array}$ & $\begin{array}{r}175 \\
(22.2)\end{array}$ & $\begin{array}{r}1,222 \\
(19.6)\end{array}$ & & $\begin{array}{r}618 \\
(21.9)\end{array}$ & $\begin{array}{r}519 \\
(21.9)\end{array}$ & $\begin{array}{r}189 \\
(21.0)\end{array}$ & $\begin{array}{l}1,326 \\
(21.8)\end{array}$ & \\
\hline & 4번이상 & $\begin{array}{r}83 \\
(3.0)\end{array}$ & $\begin{array}{r}82 \\
\text { (3.) }\end{array}$ & $\begin{array}{r}29 \\
(3.7)\end{array}$ & $\begin{array}{r}194 \\
(3.1)\end{array}$ & & $\begin{array}{r}118 \\
(4.2)\end{array}$ & $\begin{array}{r}88 \\
(3.7)\end{array}$ & $\begin{array}{r}34 \\
(3.8)\end{array}$ & $\begin{array}{r}240 \\
(3.9)\end{array}$ & \\
\hline & 모르겠음 & $\begin{array}{r}67 \\
(2.4) \\
\end{array}$ & $\begin{array}{r}80 \\
(3.0) \\
\end{array}$ & $\begin{array}{r}27 \\
(3.4) \\
\end{array}$ & $\begin{array}{r}174 \\
(2.8) \\
\end{array}$ & & $\begin{array}{r}46 \\
(1.6) \\
\end{array}$ & $\begin{array}{r}63 \\
(2.7) \\
\end{array}$ & $\begin{array}{r}37 \\
(4.1) \\
\end{array}$ & $\begin{array}{r}146 \\
(2.4) \\
\end{array}$ & \\
\hline & 전체 & $\begin{array}{r}2,763 \\
(100.0) \\
\end{array}$ & $\begin{array}{r}2.691 \\
(100.0) \\
\end{array}$ & $\begin{array}{r}790 \\
(100.0)\end{array}$ & $\begin{array}{r}6,244 \\
(100,0)\end{array}$ & & $\begin{array}{r}2,821 \\
(100.0)\end{array}$ & $\begin{array}{r}2.372 \\
(100.0) \\
\end{array}$ & $\begin{array}{r}902 \\
(100.0)\end{array}$ & $\begin{array}{r}6,095 \\
(100.0)\end{array}$ & \\
\hline \multirow[t]{3}{*}{ 흡연경험여부 } & 예 & $\begin{array}{r}228 \\
(8.2)\end{array}$ & $\begin{array}{r}237 \\
(8.8)\end{array}$ & $\begin{array}{r}85 \\
(10.7)\end{array}$ & $\begin{array}{r}550 \\
(8.8)\end{array}$ & .093 & $\begin{array}{r}624 \\
(22.1)\end{array}$ & $\begin{array}{r}512 \\
(21.6)\end{array}$ & $\begin{array}{r}285 \\
(31.6)\end{array}$ & $\begin{array}{l}1,421 \\
(23.3)\end{array}$ & .000 \\
\hline & 아니오 & $\begin{array}{l}2,538 \\
(91.8)\end{array}$ & $\begin{array}{l}2,453 \\
(91.2)\end{array}$ & $\begin{array}{r}707 \\
(89.3)\end{array}$ & $\begin{array}{l}5,698 \\
(91.2)\end{array}$ & & $\begin{array}{l}2,199 \\
(77.9)\end{array}$ & $\begin{array}{l}1,857 \\
(78.4)\end{array}$ & $\begin{array}{r}616 \\
(68.4)\end{array}$ & $\begin{array}{l}4,672 \\
(76.7)\end{array}$ & \\
\hline & 전체 & $\begin{array}{r}2,766 \\
(100.0)\end{array}$ & $\begin{array}{r}2,690 \\
(100.0) \\
\end{array}$ & $\begin{array}{r}792 \\
(100.0)\end{array}$ & $\begin{array}{r}6,248 \\
(100.0)\end{array}$ & & $\begin{array}{r}2,823 \\
(100.0)\end{array}$ & $\begin{array}{r}2,369 \\
(100.0)\end{array}$ & $\begin{array}{r}901 \\
(100.0)\end{array}$ & $\begin{array}{r}6,093 \\
(100.0)\end{array}$ & \\
\hline \multirow[t]{4}{*}{ 흡연상태 } & 예 & $\begin{array}{l}23 \\
(8)\end{array}$ & $\begin{array}{l}13 \\
(5)\end{array}$ & $\begin{array}{r}3 \\
(4)\end{array}$ & $\begin{array}{l}39 \\
(6)\end{array}$ & .043 & $\begin{array}{r}176 \\
(6.2)\end{array}$ & $\begin{array}{r}153 \\
(6.5)\end{array}$ & $\begin{array}{r}101 \\
(11.2)\end{array}$ & $\begin{array}{r}430 \\
(7.1)\end{array}$ & .000 \\
\hline & $\begin{array}{l}\text { 과거에는 피웠으나 } \\
\text { 현재는 끊었음 }\end{array}$ & $\begin{array}{r}135 \\
(4.9)\end{array}$ & $\begin{array}{r}170 \\
(6.3)\end{array}$ & $\begin{array}{r}52 \\
(6.6)\end{array}$ & $\begin{array}{r}357 \\
(5.7)\end{array}$ & & $\begin{array}{r}347 \\
(12.3)\end{array}$ & $\begin{array}{r}265 \\
(11.2)\end{array}$ & $\begin{array}{r}129 \\
(14.3)\end{array}$ & $\begin{array}{r}741 \\
(12.2)\end{array}$ & \\
\hline & 아니오 & $\begin{array}{l}2,608 \\
(94.3)\end{array}$ & $\begin{array}{l}2,506 \\
(93.2)\end{array}$ & $\begin{array}{r}737 \\
(93.1)\end{array}$ & $\begin{array}{l}5,851 \\
(93.7)\end{array}$ & & $\begin{array}{l}2,301 \\
(81.5)\end{array}$ & $\begin{array}{l}1,952 \\
(82.4)\end{array}$ & $\begin{array}{r}670 \\
(74.4)\end{array}$ & $\begin{array}{l}4,923 \\
(80.8)\end{array}$ & \\
\hline & 전체 & $\begin{array}{r}2.766 \\
(100.0)\end{array}$ & $\begin{array}{r}2,689 \\
(100.0)\end{array}$ & $\begin{array}{r}792 \\
(100.0)\end{array}$ & $\begin{array}{r}6,247 \\
(100.0)\end{array}$ & & $\begin{array}{r}2,824 \\
(100.0)\end{array}$ & $\begin{array}{r}2,370 \\
(100.0)\end{array}$ & $\begin{array}{r}900 \\
(100.0)\end{array}$ & $\begin{array}{r}6,094 \\
(100.0)\end{array}$ & \\
\hline 한 달 & 1일 이상 & $\begin{array}{r}61 \\
(2.2)\end{array}$ & $\begin{array}{r}49 \\
(1.8)\end{array}$ & $\begin{array}{r}18 \\
(2.3)\end{array}$ & $\begin{array}{r}128 \\
(2.0)\end{array}$ & .543 & $\begin{array}{r}261 \\
(9.3)\end{array}$ & $\begin{array}{l}233 . \\
(9.8)\end{array}$ & $\begin{array}{r}137 \\
(15.3)\end{array}$ & $\begin{array}{r}631 \\
(10.4)\end{array}$ & .000 \\
\hline 동안 흡연일 & 없음 & $\begin{array}{l}2,704 \\
(97.8)\end{array}$ & $\begin{array}{l}2,639 \\
(98.2)\end{array}$ & $\begin{array}{r}774 \\
(97.7)\end{array}$ & $\begin{array}{l}6,117 \\
(98.0)\end{array}$ & & $\begin{array}{l}2,559 \\
(90.7)\end{array}$ & $\begin{array}{l}2,136 \\
(90.2)\end{array}$ & $\begin{array}{r}758 \\
(84.7)\end{array}$ & $\begin{array}{l}5,453 \\
(89.6) \\
\end{array}$ & \\
\hline & 전체 & $\begin{array}{r}2,765 \\
(100.0)\end{array}$ & $\begin{array}{r}2,688 \\
(100.0) \\
\end{array}$ & $\begin{array}{r}792 \\
(100.0)\end{array}$ & $\begin{array}{r}6,245 \\
(100.0)\end{array}$ & & $\begin{array}{r}2,820 \\
(100.0)\end{array}$ & $\begin{array}{r}2,369 \\
(100.0)\end{array}$ & $\begin{array}{r}895 \\
(100.0)\end{array}$ & $\begin{array}{r}6,084 \\
(100.0)\end{array}$ & \\
\hline
\end{tabular}

카이제곱 검정, $\mathrm{p}<0.05$

결측자료 제외하고 카이제곱한 결과임 
김민자, 양희정, 이승연 : 도시와 농어촌지역 중·고등학생의 구강건강인식 및 구강보건 의식행태 비교연구

<표 5> 학년 · 거주지별 구강건강상태 비교

\begin{tabular}{|c|c|c|c|c|c|c|c|c|c|}
\hline \multirow{2}{*}{ 구분 } & & \multicolumn{2}{|c|}{ 우식영구치수 } & \multicolumn{2}{|c|}{ 상실영구치수 } & \multicolumn{2}{|c|}{ 충전영구치수 } & \multicolumn{2}{|c|}{ 우식경험영구치수 } \\
\hline & & $\mathrm{M} \pm \mathrm{SE}$ & $p$ & $\mathrm{M} \pm \mathrm{SE}$ & $p$ & $\mathrm{M} \pm \mathrm{SE}$ & $p$ & $\mathrm{M} \pm \mathrm{SE}$ & $p$ \\
\hline \multirow[t]{4}{*}{ 중학생 1학년 } & 대도시 & $0.60 \pm 1,419 b$ & .001 & $0.01 \pm 0.109 a$ & .076 & $2.03 \pm 2.656$ & .199 & $2.64 \pm 2.970$ & .213 \\
\hline & 중소도시 & $0.56 \pm 1,374 b$ & & $0.01 \pm 0.145 b$ & & $2.16 \pm 2.811$ & & $2.74 \pm 3.091$ & \\
\hline & 농어촌 & $0.39 \pm 0.957 a$ & & $0.00 \pm 0.036 a$ & & $2.14 \pm 2.771$ & & $2.53 \pm 2.894$ & \\
\hline & 전체 & $0.56 \pm 1.350$ & & $0.01 \pm 0.120$ & & $2.10 \pm 2.739$ & & $2.67 \pm 3.014$ & \\
\hline \multirow{4}{*}{$\begin{array}{l}\text { 고등학생 } \\
\text { 1학년 }\end{array}$} & 대도시 & $0.56 \pm 1.300$ & .000 & $0.01 \pm 0.152$ & .404 & $2.21 \pm 2.826 a$ & .000 & $2.78 \pm 3.095 a$ & .000 \\
\hline & 중소도시 & $0.68 \pm 1.434$ & & $0.02 \pm 0.203$ & & $2.29 \pm 2.941 a$ & & $2.99 \pm 3.213 a$ & \\
\hline & 농어촌 & $0.91 \pm 1.755$ & & $0.02 \pm 0.124$ & & $2.65 \pm 3.268 b$ & & $3.58 \pm 3.557 \mathrm{~b}$ & \\
\hline & 전체 & $0.66 \pm 1.433$ & & $0.02 \pm 0.171$ & & $2.30 \pm 2.943$ & & $2.98 \pm 3.224$ & \\
\hline
\end{tabular}

* one way ANOVA

$\dagger$ a,b,c means followed by different letters are significantly different at $a=0.05$

\section{$\mathrm{IV}$. 결론}

학생 연령층에서는 우식증의 발생률이 높고 점 진적으로 치주병을 야기할 수 있는 치은염도 발생 하기 시작하는 시기이다. 특히 청소년기에는 치아 우식증이 계속 진행되는 연령이며 치주병이 시작 하는 시기이므로 예방관리가 중요하다[13]. 또한 치아우식증은 여러 가지 요인들이 작용하는 다인 성 질환이며 지금까지 치아우식증에 발생하는 요 인에는 지역, 성별, 사회경제적 지위, 구강보건형 태, 그리고 탄산음료나 설탕이 함유된 음식의 섭취 등이 알려져 있다[14]. 치아우식증은 우리나라 대 부분의 사람들이 경험하는 질병으로 특히 5-17세 아동 및 청소년들에서 만성적으로 유행하는 질환 으로 알려져 있다[15]. 우식경험 영구치율(DMF rate)은 2003년도에 중학생은 $81.57 \%$, 고등학생은 $90.17 \%$ 이었고, 2006 년도에 중학생은 $73.6 \%$, 고등학 생은 $79.5 \%$ 이었으며 2010년도에는 중학생은 $65.8 \%$, 고등학생 $80.7 \%$ 이었다[3][16]. 이전 실태조 사와 비교해보면 많이 줄었다고는 할 수 있으나 아직 구강건강에 대한 인식은 미흡한 상태이다. 우 리나라 대부분의 인구가 가지고 있는 질병 중의 하나로서 개인이 관심을 가지고 인식 및 생활습관
등에 변화를 가진다면 충분히 예방할 수 있는 질 병이기도 하다. 또한 청소년기의 구강건강은 성인 의 구강건강의 바탕이 되므로 중·고등학생의 구 강관리는 매우 중요하다고 할 수 있다.

우리나라의 거주지별 중·고등학생의 구강건강 인식 및 구강보건의식행태를 알아보기 위해 시행 한 이 연구에서 대도시, 중소도시, 농어촌 지역 간 의 구강건강 인식 및 구강진료기관 이용실태, 구강 보건인식행태, 학년·거주 지역별 구강건강상태를 파악한 결과 대부분이 연령에 따라 차이가 나타날 수 있으나 지역과 같은 환경적 요인도 영향이 있 다는 것을 알 수 있다.

군지역은 대도시 지역에 비해서 우식치면수와 우식치수가 각각 $0.8042,0.2970$ 만큼 유의하게 많 았으며 충전치면수와 충전치수는 각각 1.9642 , 0.6493 만큼 유의하게 작았다. 또한 지역사회 치주 지수는 군지역이 대도시에 비해서 0.1953 만큼 유 의하게 높았다. 보철필요율은 중소도시 지역과 군 지역이 대부분에서 대도시에 비해서 유의하게 높 은 결과를 보였는데 하악의 경우, 대도시에 비해서 중소도시 지역이 $4.73 \%$, 군지역이 $9.57 \%$ 유의하게 높은 필요율을 보였다. 상악의 경우도 중소도시 지 역이 통계적으로 유의하지는 않았으나 대도시에 
비해서 $3.14 \%$ 높은 필요율을 보였고 군지역은 $8.27 \%$ 유의하게 높은 필요율을 보였다. 상하악을 모두 합친 전체 보철필요율은 중소도시 지역과 군 지역 모두에서 대도시에 비해서 유의하게 $4.57 \%$, $10.52 \%$ 높았다[17].

구강건강은 저작 기능, 의사소통 등의 사회적 기능, 심미적 측면을 통해 일상생활을 하는 데 있 어 중대한 영향을 미친다. 자신의 구강건강에 대한 인식도는 주관적인 방법이지만 구강건강을 평가하 는데 중요한 기준 중의 하나이며, 여러 연구에서 구강건강에 대한 치과의사의 객관적 평가와 주관 적 인식도 사이에 연관성이 있음을 보고 하였다 [18]. 일부 외국의 연구에서는 도시외곽이나 읍지 역에 사는 사람들의 건강수준이 가장 높으며 산간 벽지나 도시 내부에 사는 사람들의 건강수준이 가 장 낮음을 보고하고 있기도 한데 이와 같은 도시 화의 정도에 따라 건강수준 간의 비선형적인 관계 는 도시화의 정도에 따라 건강수준에 영향을 미치 는 사회환경 요인들이 서로 다른 기전이나 정도로 사람들에게 영향을 미치고 있음을 시사한다[19].

구강보건의식행태 중 잇솟질 시기의 경우에는 대도시의 경우 잠자기 직전 다른 지역에 비해 잇 솔질을 많이 하는 것으로 나타났으며 중소도시의 경우 저녁 식사 후 잇솔질을 다른 지역에 비해 많 이 한다고 응답 하였으며 농어촌의 경우 다른 지 역에 비해 점심 식사 후에 잇솔질을 한다는 비율 이 다른 지역에 비해 높았다. 대부분의 학생들이 아침 식사 후에, 저녁 식사 후에 잇솔질을 한다는 응답이 가장 많았으나 아침 식사 전이나 점심 식 사 후에 잇솔질을 한다는 응답을 한 학생도 많이 조사되어 구강건강인식 및 구강보건의식의 체계적 이고 학생 눈높이에 맞는 체계적인 교육과 관심이 필요할 것으로 생각된다. 이러한 결과를 살펴보면 잇솔질이 치아우식증의 원인이 되는 치면세균막을 관리해 줄 수 있는 가장 기본적인 방법임에도 불 구하고 잇솔질을 구강병 예방 행위라기보다는 단
순히 일상생활습관의 하나로 여기며 특히 연구 대 상자들이 청소년인 점으로 보아 자신들의 구강건 강 행동을 정확히 파악하지 못한 것에 기인한다 하겠다[20]. 한편 Levine 등은 11-15세에 잇솔질을 가끔 하거나 거의 하지 않은 아이들의 $52 \%$ 에서 치 아우식증이 없었고 평균우식경험영구치지수가 1.05 인 반면에 하루에 최소 한 번 이상 잇솔질을 하는 아이들에서는 $69 \%$ 가 치아우식증이 없었고 평균우 식경험영구치지수는 0.69 로 잇솔질 횟수와 치아우 식증은 역상관계가 있다고 하였다[21].

충치유발과 관련이 있는 1 일 우식성간식섭취와 관련해서는 중학생의 경우 농어촌지역 일수록 우 식성 간식섭취 횟수와 비율이 많아지고 있음을 알 수 있으며 우식성 음료섭취 횟수 또한 농어촌 지 역으로 갈수록 횟수와 비율이 높은 것을 알 수 있 다. 한편 고등학생의 경우 이와는 반대로 대도시 지역일수록 우식성 음식섭취 횟수와 음료섭취 횟 수가 중학생과는 반대의 현상이 일어났다. 따라서 전반적으로 충치의 유발을 줄이는 대체식품에 대 한 교육이 필요하며 농어촌 및 대도시 학교주변에 대한 유해성음식에 대한 규제가 필요하다고 생각 한다.

흡연경험여부는 농어촌의 경우 대도시의 중·고 등학생 흡연 비율보다 높았으며 현재 흡연을 하고 있거나 과거에 피웠던 비율 또한 높게 나타나고 있다. 선행연구를 살펴보면 많은 우리나라 청소년 들이 스트레스 해소방안의 하나로 흡연을 생각할 수 있으므로 이에 대한 교육의 시급함을 주장하였 고, 흡연집단이 비흡연 집단에 비해 다양한 생활 사건과 관련된 스트레스를 더 받고 있다고 보고한 바 있다[22]. 한 연구에서 농어촌지역 어린이들의 첫 흡연동기가 아버지나 주변 어른의 권유에 의한 경우가 많았고[23], 다른 연구에서는 흡연 장소가 학교인 경우가 도시에 비해 훨씬 높았고 집이나 친구 집인 경우도 가장 높았는데 이러한 상황은 농어촌 지역이 도시지역에 비해 청소년 흡연에 대 
해 사회적 규범이 더욱 관대하거나 규제가 약할 가능성이 높음을 시사한다고 하였다[24].

거주 지역별 영구치 우식경험자는 지역별로 중 학생의 경우 대도시의 학생의 평균이 높게 나타났 으며 고등학생의 경우 이와 반대로 농어촌지역으 로 갈수록 평균이 높게 나타났다. 우리나라 12세 아동의 우식경험영구치 지수를 살펴보면 1978년에 는 도시지역에 2.6개, 전원지역에 1.7 개 이었으나, 1995년에는 도시지역 2.9개, 전원지역 3.3개, 2000 년도 조사에서는 도시지역 3.11개, 농어촌지역 3.40 개로 계속 증가되었다[25]. 이는 앞에서 나타난 구 강보건의식 행태 중 잇솔질 시기와 생활환경과도 관련이 있다는 생각을 한다.

본 연구결과에서 나타난 것과 같이 우리나라 중 고등학생의 구강건강인식 및 구강보건인식행태를 지역별로 비교 분석한 의미 있는 연구로서 향후 학생들은 자신의 구강상태에 대한 정확한 인식과 치료 관리에 대한 노력을 기울여야 하며 학교에서 는 구강보건에 대한 정확하고 체계적인 교육 및 실습이 동시에 이루어 져야한다. 또한 정부에서도 지역별 차등 없는 정책이 지속적으로 지원되어야 할 것이다.

\section{V. 제언}

본 연구에서는 중·고등학생의 지역별 구강건강 인식 및 구강진료기관 이용실태와 구강보건의식행 태, 그리고 학년 - 거주지역별 구강건강상태 비교를 통해 지역에 따른 관련성을 확인 하고자 우리나라 중고등학생 12,325명을 대상으로 2010년 국민구강 건강실태조사 분석 자료를 이용하여 연구를 시행 하였다.

첫째, 구강건강인식 및 구강진료 이용실태를 비 교한 결과 중학생의 경우 도시지역에서 농어촌지 역으로 갈수록 자신의 건강에 대해 건강하지 못하 다는 응답을 많이 하였으며, 고등학생 역시 농어촌
지역으로 갈수록 건강상태에 대한 인식이 낮아지 는 결과를 보여주고 있다.

둘째,. 거주지역에 따른 구강보건의식행태 중 잇 솔질 시기에서는 중·고등학생 모두 점심식사 후 잇솔질은 한다는 응답이 가장 많았으며 저녁식사 후, 잠자기 전에 잇솔질은 한다는 응답 또한 많이 나왔으며 중학생과 고등학생 각각 지역별 유의한 차이를 보이고 있었다. 우식성 간식섭취 횟수와 관 련해서는 중학생의 경우 지역별 유의한 차이를 보 이지 않았으나, 한편 고등학생의 경우 농어촌지역 으로 갈수록 우식성 음식섭취 횟수와 음료섭취 횟 수가 중학생과는 다르게 농어촌 지역이 많은 비율 을 나타났으며 통계적으로 유의한 차이를 보이고 있다.

다른 구강보건의식행태(흡연경험여부, 흡연상태, 한 달간의 흡연일)중 중학생의 경우 지역별 유의한 차이가 없었으나 고등학생의 경우 나머지 구강보 건의식행태의 경우 모두 유의한 차이를 보이고 있 어 개선이 필요한 실정이다.

셋째, 학년·거주지역별 구강건강상태를 비교한 결과 중학생의 경우 대도시의 우식영구치수 평균 이 높았으나 고등학생의 경우 농어촌으로 갈수록 중학생과 반대되는 사례를 보이고 있어 거주지역 에 따라 우식영구치수는 유의한 차이가 있음을 알 수 있다. 상실영구치수, 충전영구치수, 우식경험영 구치수의 경우 중학생은 지역별로 유의한 차이를 보이지 않았으나 고등학생의 경우 우식영구치수와 같이 대도시에서 농어촌 지역으로 갈수록 평균이 높게 나타나 지역에 따라 영구치수는 유의한 차이 가 나타남을 알 수 있었다.

이 결과는 중·고등학생의 구강건강인식 및 구 강보건의식행태가 도시, 중소도시, 농어촌 등 지역 에 따라 관계가 있음을 알 수 있었으며 중·고등 학생이 아닌 유아기부터의 체계적인 구강보건교육 이 이루어 져야 할 것이며 지역별 맞춤형 지원 정 책이 이루어져야 할 것으로 사료된다. 


\section{참고문헌}

1. 이숙정, 김창환, 최규일(2012), 노인의 주관적 구강 건강상태 및 구강보건행태에 영향을 미치는 요인, 보건의료산업학회지, Vol.6(1);39-51.

2. 정영정, 정서영, 강병진, 백광우(2009), 소년원 학 교 학생의 구강건강 실태와 구강건강 인식도, 대 한소아치과학회지, Vol.38(4);539-549.

3. 보건복지부(2010), 2010년도 국민구강건강실태 조 사, 보건복지부.

4. 질병관리본부(2006), 2005 청소년건강행태조사, 질 병관리본부.

5. M.H. Baldani, and J.L. Antunes(2011), Inequalities in Access and Utilization of Dental Services: A Cross-sectional Study in an Area Covered by the Family Health Strategy, Cad Saude Publica, Vol.27(2);272-283.

6. Ministry of Health \& Welfare(2011), 2010 Korea National Oral Health Survey: II. Survey Results. Seoul: Ministry of Health \& Welfare, pp.116-120.

7. 전지은, 정원균, 김남희(2012), 우리나라 국민의 인 구사회경제특성에 따른 치과진료 미충족 이유: 제 4 기 국민건강영양조사 자료를 이용하여, 대한구강 보건학회지, Vol.36(1);73-81.

8. 이정희, 전은숙(2011), 일부 대학생들의 흡연유뮤 및 계열에 따른 구강관리 행태 및 관심도에 관한 조사, 보건의료산업학회지, Vol.5(3);169-177.

9. 김수경(2008), 초등학생의 구강건강증진 행위 모형 개발, 한양대학교 대학원 박사학위논문, pp.84-86.

10. 김영선, 윤희숙(2006), 일부 치위생과학생의 구강 건강인식 및 행동과 주관적 구취인지 유무와의 관련성, 한국위생과학회지, Vol.12(2);79-86.

11. 강복희, 박선남, 송경애, 문정순(2008), 잇솔질 교 육 프로그램이 학령전기 아동의 구강건강에 미치 는 효과, 대한간호학회지, Vol.38(6);914-922.

12. 김수경, 김영수(2008), 초등학생의 구강건강증진 행위 모형, 대한구강보건학회지, Vol.32(4);563-574.
13. 김종배, 최유진, 백대일, 신승철, 김동기(1991), 임 상예방치학, 이우문화사, pp.83-92.

14. 예방치학연구회(2007), 현대예방치학, 군자출판사, pp.29-52.

15. 예방치학연구회(2008), 현대예방치학, 군자출판사, pp.275-297.

16. 보건복지부(2006), 2006년도 국민구강건강실태 조 사, 보건복지부.

17. 최연희, 이정희, 이상규(2009), 우리나라 대소시, 중소도시, 군지역간 성인 구강건강 수준의 차이, 대한구강보건학회지, Vol.33(2);243-253.

18. A.L. Ostberg, B. Eriksson, U. Lindblad, and A. Halling(2003), Epidemiological Dental Indices and Self-perceived Oral Health in Adolescents: Ecological Aspects, Acta Odontol Scand, Vol.61;19-24.

19. G. Bentham(1984), Mortality Rates in the more Rural Areas of England and Wales, Area, Vol.16;219-226.

20. 신선행, 김명석(2009), 흡연청소년의 치아우식 증 경험도 및 구강위생 관련 요인, 한국치위생학회, Vol.9(5);497-506.

21. R.S. Levine, Z.J.Nugent, M.C. Rudolf, and P. Sahota(2007), Dietary Patterns, Toothbrushing Habits and Caries Experience of Schoolchildren in West Yorkshire, England, Community Dent Health, Vol.24(2);82-87.

22. 김신정, 양순옥(2002), 중학생의 흡연에 대한 지 식 및 태도, 아동간호학회지, Vol.8(2);152-163.

23. S.W.Lee, and S.W. Park(2005), Smoking Behaviors and Associated Factors among Elementary School Students in a Rural Area, J Korean Soc Matern Child Health, Vol.8(1);73-84.

24. 박순우(2009), 농어촌지역 청소년의 건강행태, 농 촌의학 · 지역보건, Vol.34(2);202-213.

25. 한국구강보건의료연구원(2001), 2000년도 국민구 강건강실태조사 심층분석 연구보고서. 한국구강보 건의료연구원, pp.9-12. 
김민자, 양희정, 이승연 : 도시와 농어촌지역 중·고등학생의 구강건강인식 및 구강보건 의식행태 비교연구

접수일자 2012년 11월 8일

심사일자 2012년 11월 20일

게재확정일자 2012년 12월 19일 